\title{
Sediment processing and selective feeding by Pectinaria koreni (Polychaeta: Pectinariidae)
}

\author{
Fred C. Dobbs* \& Teresa A. Scholly* \\ Department of Genetics and Ecology, Aarhus University, Aarhus, Denmark
}

\begin{abstract}
Pectinaria (Lagis) koreni (Malmgren) is an abundant, deposit-feeding, infaunal inhabitant of shallow-water marine environments in northern Europe. Laboratory experiments were performed to quantify the polychaete's sediment processing in 2 distinct sediments, 1 fine-grained and high in combustibles, the other coarse-grained and low in combustibles. Gut passage time and time to pseudodefecation were predictable only in coarse-grained sediment. In both sediments, reworking rate increased with worm size and over time, although temporal patterns differed in the 2 sediments. The ratio of pseudodefecated sediment to defecated sediment did not differ significantly over time in either sediment, but the ratio was greater in the fine-grained sediment during the first measurement period. Another thrust of this study was to investigate possible size-selective ingestion of sediment particles by P. koreni. Results corroborated previous workers' findings that pectinariids selectively ingest large particles, a behavior at variance with current perceptions of optimal foraging by deposit feeders. These experiments were supplemented by natural history observations of the worm's infaunal behavior and particle-handling techniques.
\end{abstract}

\section{INTRODUCTION}

An intimate knowledge of the sediment-processing behavior of deposit-feeding macrobenthos is essential to understanding its influence on the physical, chemical, and biological properties of marine sedimentary environments. For sessile or discretely motile infauna (Fauchald \& Jumars 1979), feeding behavior is of primary importance because it involves more sediment than does construction of burrows or tubes. In this paper, we examine sediment processing by Pectinaria (Lagis) koreni (Malmgren), a tubicolous polychaete annelid common in shallow-water sediments throughout northern Europe. Despite previous interest in the ecology of this species (Watson 1928, Lindroth 1941, Wilcke 1952, Schäfer 1956, 1972, Vouvelle 1971, 1973, Nichols 1977. Bachler 1981, Reise 1981, Nicolaidou 1983), there exists no published information on its rate of sediment processing. Here we quantify vertical transport of sediment by $P$. koreni in different sediments, over time and

\footnotetext{
- Present address: Department of Oceanography, The Florida State University, Tallahassee, Florida 32306-3048, USA. Address reprint requests to F. C. Dobbs
}

as a function of worm size. We also examine the possibility that size-selective ingestion of sediment particles by $P$. koreni confounds current perceptions of optimal foraging by deposit feeders. That is, organisms should select smaller particles because their food value should be intrinsically greater per unit volume (Taghon et al. 1978, Taghon 1982). In studies of other pectinariids, Whitlatch (1974), Ronan (1977), and Whitlatch \& Weinberg (1982) found selection for larger, not smaller particles.

Pectinaria koreni is found inter- and subtidally in a range of sandy to muddy sediments, e.g. biofacies 3,4, 7 , and 10 of Schäfer (1972). It lives below the sediment surface, anterior end down, in a cone-shaped tube. The tube, open at both ends and composed of a monolayer of sand grains, is oriented obliquely or perpendicularly to the sediment surface. The narrow posterior end is either flush with the surface or protrudes slightly. The worm collects subsurface sediment with its tentacles. Mineral grains and detrital particles are transported along each tentacle's ciliated groove to the worm's mouth. As with at least several other pectinariids, unconsolidated feces are propelled from the tube and fall onto the adjacent sediment surface. The worm also 
produces unconsolidated pseudofeces that are texturally indistinguishable from feces. Pseudofeces are sediment particles that are transported from feeding depths, moved upward between the worm and its tube, and ejected (Watson 1928, Schäfer 1972). Rhoads (1974) has classified pectinariids and other benthic invertebrates that relocate material from depth to the sediment surface as 'conveyor-belt species'. For one such species of polychaete, Dobbs \& Whitlatch (1982) reported a behavior in which the worm collected surface particles. With this observation in mind, a final objective of the present study was to determine if $P$. koreni collected material from the sediment-water interface.

\section{MATERIALS AND METHODS}

Organisms and sediments. Worms were collected from sediment brought up with a dredge in the Limfjord near Rønbjerg, Denmark and in Aarhus Bay, Denmark. They were maintained at the Institute for Genetics and Ecology, Aarhus University, for up to 9 mo in a mixed sediment (approximately equal portions from the Limfjord and Moesgaard Beach: see below). Temperature and salinity of the maintenance aquaria were $15^{\circ} \mathrm{C}$ and $25 \mathrm{ppt}$, respectively; all experiments described in this paper were run under these conditions. Rehydrated Tetramin fish food was sprinkled on the sediment surface weekly.

As a convenient, non-lethal measure of worm size, we used the outer diameter of the anterior tube opening (ATD), which was highly predictive of the worm's cephalic plate width (CPW) and body length $(\mathrm{BL})$, i.e. $\mathrm{CPW}=.904 \mathrm{ATD}-.199, \mathrm{r}^{2}=.98, \mathrm{n}=38$; $\mathrm{BL}=4.15 \mathrm{ATD}+.985, \mathrm{r}^{2}=.83, \mathrm{n}=28$. All measurements were made using the ocular micrometer of a dissecting microscope and were expressed in $\mathrm{mm}$. Additional biometrics pertinent to Pectinaria koreni are provided by Nicolaidou (1983).

Sediments dredged from the Limfjord and Aarhus Bay, hereafter called experimental sediments, were characterized with respect to percent weight loss on combustion (dried at $60^{\circ} \mathrm{C}$, weighed, then $24 \mathrm{~h}$ at $480^{\circ} \mathrm{C}$ ), particle-size distribution (wet-sieving technique; refer to experiments on particle-size selectivity for details), and by qualitative microscopic inspection. A third experimental sediment, collected in $1 \mathrm{~m}$ of water at Moesgaard Beach, a site on Aarhus Bay, was also characterized. In very limited sampling, we found no Pectinaria koreni at Moesgaard Beach. Following their collection, experimental sediments were kept frozen until use.

Laboratory observations of infaunal behavior. Several times during the study, 3 or 4 Pectinaria koreni were added to thin-wall plexiglass aquaria filled with sediment from either the Limfjord or Moesgaard Beach. The thin-wall aquaria were placed in a larger glass aquarium filled with seawater. An aquarium pump was used to provide aeration. Behavior of the worms was observed for more than $50 \mathrm{~h}$ through a horizontally-mounted dissecting microscope.

Gut passage time and time to pseudodefecation. To determine the time required for these 2 modes of sediment processing, worms were taken from maintenance microcosms and placed in sediment from either Moesgaard Beach ( $\mathrm{n}=36$ worms) or the Limfjord ( $\mathrm{n}=66$ worms). These experimental sediments had been stained with methylene blue and rinsed to remove excess stain. The worms burrowed immediately. A collar of filter paper was placed over the protruding end of each worm's tube. When reworked blue sediment appeared on the filter paper, the elapsed time was noted and the worm was removed. Its tube was dissected and the posterior section of the worm's gut was inspected using a dissecting microscope. If blue sediment was present in the posterior portion of the intestine, the reworked sediment was scored as 'defecated'. If no blue sediment was seen, the reworked sediment was scored as 'pseudodefecated'.

Reworking rate. To measure reworking rates, worms were placed individually into $100 \mathrm{ml}$ glass beakers containing 75 to $80 \mathrm{ml}$ of sediment from either Moesgaard Beach or the Limfjord. A large number and size range of worms were used for each sediment type (see 'Results' for details). After they burrowed, reworked sediment was collected on filter paper placed around the protruding posterior ends of their tubes (Rhoads 1963, Gordon 1966). Reworked sediment was collected with a pipet, preserved in $70 \%$ ethanol, dried to constant weight at $60^{\circ} \mathrm{C}$, and weighed to the nearest mg.

To determine if reworking rates of individual worms varied according to time spent in the sediment, rates were measured during 3 periods after placing the worms in the beakers (Period $\mathrm{A}=12$ to $36 \mathrm{~h} ; \mathrm{B}=89$ to $119 \mathrm{~h} ; \mathrm{C}=161$ to $191 \mathrm{~h}$ ). During each period, 3 or 4 rate measurements, each lasting 6 or $12 \mathrm{~h}$, were made on each worm. However, only 1 rate measurement was made on worms in Moesgaard Beach sediment during Period A.

Since reworking rate increased with worm size (see Fig. 4 \& 5), worm size had to be considered as a covariate. To compare reworking rate among times using analysis of covariance, one must assume that the slope relating $\log _{10}$ reworking rate to worm size (the covariate) is common at all times. However, these data violate this assumption and analysis of covariance was not used. As an alternative, the data were transformed to make them independent of worm size, then tested for differences over time. To transform the data, a leastsquares regression relating $\log _{10}$ reworking rate $(\mathrm{Y})$ to 
anterior tube diameter (X) was calculated for each time-sediment combination. Thus, 6 equations were calculated in all ( 2 sediments $\times 3$ time periods). Residuals $\left(\mathrm{Y}_{\mathrm{i}}-\hat{\mathrm{Y}}\right)$ about each regression line represent the magnitude of the reworking rate that could not be explained by its relation to worm size. It is reasonable, therefore, to assume that the residual is a function only of the time treatment or random error component. Random error was assumed to be equal over all time treatments. Therefore, any differences in the magnitude of the residuals among times would suggest that reworking rate changes with time. To keep the average reworking rate of the transformed data identical to that of the $\log _{10}$ data, the $\log _{10}$ mean $(\bar{Y})$ was added to the residuals. These transformed data $\left[\overline{\mathrm{Y}}+\left(\mathrm{Y}_{\mathrm{i}}-\overline{\mathrm{Y}}\right)\right]$ were used to test for time effects. In each sediment separately, transformed reworking rates were examined over time using a repeated-measures design analysis of variance (Winer 1971, p. 261). Differences in transformed reworking rates between sediments were tested separately for each time period using a t-test. The $95 \%$ significance level was used in these and all analyses.

Defecation and pseudodefecation rate. Nichols (1974) method was used to estimate rates of defecation and pseudodefecation for worms that had been living in sediment from either Moesgaard Beach or the Limfjord for 16,95 and $167 \mathrm{~h}$. These times were chosen to correspond to Periods $\mathrm{A}, \mathrm{B}$, and $\mathrm{C}$ of the reworking experiment. Total reworking (defecated and pseudodefecated material) was determined, as above, for a $6 \mathrm{~h}$ period. Worms were then removed from the sediment, any adhering particles were washed away, and the worms were placed in Petri dishes containing only paper-filtered (Whatman \#2) seawater. After $6 \mathrm{~h}$, all sediment in the dishes (defecated material only) was collected, dried, and weighed as above. Ratios of pseudodefecation rates to defecation rates were calculated. These data could not be made normal with any standard transformation, so nonparametric analyses (Hollander \& Wolfe 1973) were used on the original data. For each sediment, a Kruskal-Wallis test was performed on the ratios to determine if they varied over time. For each time period, a Wilcoxon Rank Sum test was used to compare ratios obtained in the 2 sediments.

Particle-size selectivity. To test for size-selective feeding, 10 large worms ( 4.10 to $7.33 \mathrm{~mm}$ ATD) were placed individually in plastic core liners $(12 \mathrm{~cm}$ deep $\times 2.6 \mathrm{~cm}$ i.d.) three-quarters filled with sediment from Aarhus Bay. This experimental sediment was chosen because it had a greater size range of particles than the other experimental sediments. The worms burrowed quickly and began reworking. After $72 \mathrm{~h}$, sediment and worm were carefully extruded and a sediment sample was collected with a spatula at the level of the worm's feeding cavern. This sample, hereafter termed ambient sediment, and the worm were immediately preserved in $70 \%$ ethanol. (A preliminary experiment had shown that ethanol did not cause live worms to regurgitate or defecate sediment.) To estimate particle-size distributions of the samples from the ambient sediment and the entire contents of the worm's dissected gut, the samples were wet-sieved through miniature nested sieves $(1,000,500,250,125$, and $63 \mu \mathrm{m})$ using paper-filtered (Whatman \#2) seawater. Cammen (1982) showed that gentle wet sieving causes essentially no change in a sediment's particle-size distribution. The fraction $<63 \mu \mathrm{m}$ was collected by vacuum filtration on previously dried and weighed filters (Gelman, pore size $=0.4 \mu \mathrm{m}$ ). All fractions were rinsed with distilled water to remove excess salts, washed into tared trays, and dried to constant weight at $60^{\circ} \mathrm{C}$.

A graphic median sediment size was determined for each of 20 samples $(10$ gut contents, 10 ambient sediments). A 1-tailed, Wilcoxon Signed Rank test was performed to test the hypothesis that median particle size in gut contents was larger than median particle size in ambient sediments. We chose a one-sided hypothesis because other investigators have demonstrated selectivity for large particles in other pectinariids (Whitlatch 1974; Ronan 1977, Whitlatch \& Weinberg 1982). Since 7 samples of ambient sediment contained particles $>1,000 \mu \mathrm{m}$, a second Wilcoxon Signed Rank test was performed on medians recalculated after values $>1,000 \mu \mathrm{m}$ were eliminated from the data. The rationale for the second test arose from preliminary experiments in which the upper limit of ingested particles was 600 to $700 \mu \mathrm{m}$ (longest dimension). Finally, Ivlev's (1961) coefficient of feeding selectivity was calculated, $E_{1}=\left(r_{2}-p_{1}\right) /\left(r_{i}+p_{i}\right)$, where $r_{1}$, $p_{i}$ represent the percentage (by weight) of the ith particle size ingested and in the environment, respectively. Coefficient values range from -1 , indicating avoidance, to +1 , indicating preference. A value of 0 indicates no selection. Coefficients were calculated for each particle size class for each worm.

\section{RESULTS}

\section{Description of experimental sediments}

Characteristics of the experimental sediments are presented in Table 1 and Fig. 1. Sediments from Aarhus Bay and the Limfjord both were about 10 times higher in combustibles than sediment from Moesgaard Beach. The relatively well-sorted beach sediment was composed almost entirely of quartz grains with little to 
Table 1. Characteristics of experimental sediments

\begin{tabular}{|c|c|c|c|}
\hline Characteristic & Limfjord & Moesgaard Beach & Aarhus Bay \\
\hline $\begin{array}{l}\% \text { Weight loss on combustion: } \\
\text { mean (SD), } n=3\end{array}$ & $5.45(.05)$ & $0.65(.07)$ & $6.50(0.35)$ \\
\hline \multicolumn{4}{|l|}{ Composition by size fraction: } \\
\hline$\geq 1000 \mu \mathrm{m}$ & - & - & $a, b, c, d$ \\
\hline $500-1000$ & $a, b$ & $\mathrm{C}$ & $\mathrm{a}, \mathrm{b}, \mathrm{c}, \mathrm{d}, \mathrm{e}$ \\
\hline $250-500$ & $a, b, f, g$ & $\mathrm{c}$ & $a, b, c, d, e, f$ \\
\hline $125-250$ & $a, b, d, f, g, h$ & $\mathrm{c}$ & $a, b, c, d, e, f, g$ \\
\hline $63-125$ & $a, b, c, d, f, g, h, i$ & $c, d$ & $a, b, c, d, e, f, g, i$ \\
\hline$<63$ & $a, b, c, d, f, g, h, i$ & - & $a, b, c, d, f, g, i$ \\
\hline
\end{tabular}
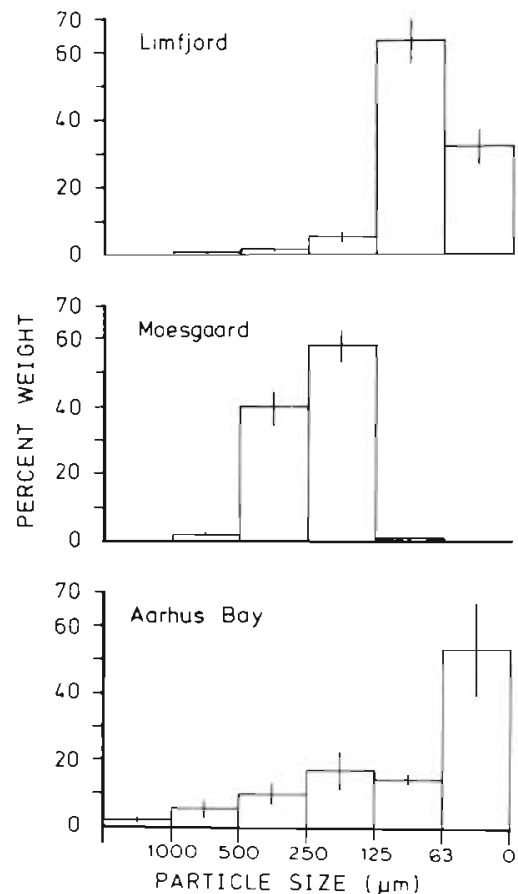

Fig. 1. Particle-size distributions of the experimental sediments. Histograms represent means of replicate analyses. Vertical lines indicate $\pm 1 \mathrm{SD}$

no encrustation and contained no material $<63 \mu \mathrm{m}$. Limfjord sediment contained a large proportion of vascular plant fragments, fecal pellets, and amorphous material. It had essentially no mineral grains $>250 \mu \mathrm{m}$. Sediment from Aarhus Bay consisted primarily of a fraction $<63 \mu \mathrm{m}$; in the larger fractions were an assortment of mineral grains, an intermediate amount of vascular plant material, and amorphous matter. Entire fecal pellets of the bivalve mollusc Abra alba were abundant in fractions from 63 to $500 \mu \mathrm{m}$.

\section{Laboratory observations of infaunal behavior}

Here we present only those observations which augment or amplify descriptions of previous workers. Although Pectinaria koreni always collected sediment particles from its feeding cavern, it also foraged with its tentacles in sub-surface sediment never oxidized by the worm's irrigation of its tube. Furthermore, in the fine-grained sediment from the Limfjord, the polychaete extended its tentacles to the sedimentwater interface and retrieved sediment from there. Surface foraging was not observed in sediment from Moesgaard Beach.

The worm's irrigation of its tube provided another mechanism for translocating surface sediment. As the worm pumped water, fine particles in suspension at the sediment-water interface sometimes were drawn into the feeding cavern.

The worm's tentacles moved through the sediment constantly. In fact, the tentacles often were not retracted prior to defecation (or pseudodefecation?). Therefore, Pectinaria koreni can collect sediment without interruption.

While probing, the tentacles' tips usually were pointed, although they would become spatulate when contact was made with a large particle, e.g. $>200 \mu \mathrm{m}$ long. Whatever the size of the particle, pick-up usually was accomplished by a tentacle's pressing against the sediment, then quickly snapping away, carrying with it at least several grains. Smaller particles were transported along the median groove of tentacles solely by means of cilia, but large particles were brought toward the mouth both by ciliary action and jerky, contractile movements of the tentacles.

As particles were moved along the tentacles, dead foraminifers, wood chips, and mollusc shell fragments dropped off. However, fecal pellets, vascular plant 
detritus, and organic mineral aggregates, all of ingestible size, also fell from the tentacles to the bottom of the feeding cavern. This 'sloppy' particle-retrieval behavior was seen constantly over time and in many individuals. The dropped particles were sometimes retrieved and ingested.

In the Limfjord's fine-grained sediment, Pectinaria koreni established U- or V-shaped burrows. The worms's tube and feeding cavern constituted one half of the burrow; an upward extension of the feeding cavern formed the other half. The worm kept this latter conduit to the surface open through irrigation and by clearing away sediment with its tentacles. In the coarser sediment from Moesgaard Beach, P. koreni did not create a burrow system.

\section{Gut passage time and time to pseudodefecation}

Vertical transport of sediment was predictably related to worm size in sediment from Moesgaard Beach (Fig. 2b \& 3b). Gut passage times ranged from 1 to $6.5 \mathrm{~h}$ in worms with anterior tube diameters from 2 to $5 \mathrm{~mm}$. In worms of similar size, the time to pseudodefecation varied from less than 0.5 to almost $3 \mathrm{~h}$. When the times obtained for worms in Limfjord sediment were regressed against worm size (Fig. 2a \& 3a), the slopes of the lines were not significantly different from 0 ( $t$ test, $\mathrm{p}>0.05)$; this result was unaffected by transforming the data. These times should be regarded as conservative estimates, because there is probably some

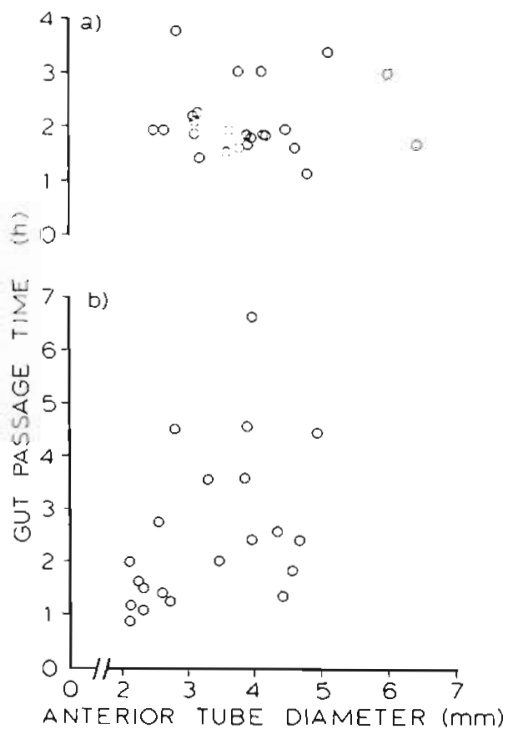

Fig. 2. Pectinaria koreni. Relation between gut passage time and anterior tube diameter in sediment from the Limfjord (a) and Moesgaard Beach (b). For Moesgaard Beach data, $\mathrm{Y}=0.699 \mathrm{X}+0.239, \mathrm{n}=21, \mathrm{r}^{2}=0.203$. The slope of the regression for Limfjord data was not significantly different from $0(\mathrm{n}=24, \mathrm{p}>0.05)$

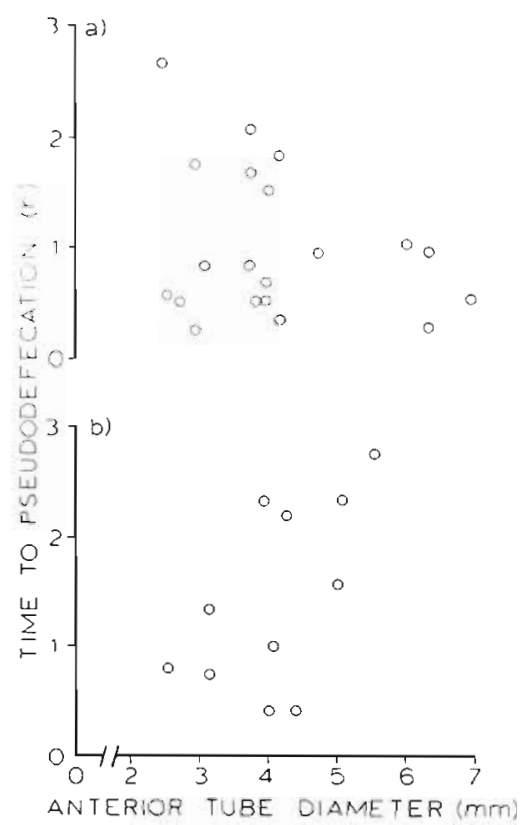

Fig. 3. Pectinaria koreni. Relation between time to pseudodefecation and anterior tube diameter in sediment from the Limfjord (a) and Moesgaard Beach (b). For Moesgaard Beach data, $\mathrm{Y}=0.556 \mathrm{X}-0.823, \mathrm{n}=11, \mathrm{r}^{2}=0.365$. The slope of the regression for Limfjord data was not significantly different from $0(n=20, p>0.05)$

lag time between placing the worm in the sediment and its resumption of normal behavior. In fact, onethird of the worms tested in sediment from the Limfjord had not reworked sediment after $10 \mathrm{~h}$ and were followed no further. Only 2 of 36 worms tested in Moesgaard Beach sediment failed to rework sediment.

\section{Reworking rate}

In both sediments, reworking rates increased exponentially as a function of increasing anterior tube diameter (Fig. 4 \& 5). Mean values ranged from 0.62 to $47 \mathrm{mg}$ worm $^{-1} \mathrm{~h}^{-1}$ in Limfjord sediment and from 0.56 to $83 \mathrm{mg}$ worm ${ }^{-1} \mathrm{~h}^{-1}$ in Moesgaard Beach sediment. Each individual's rate usually varied considerably, corroborating our observations that Pectinaria koreni defecates and/or pseudodefecates in a manner inconsistent over short periods of time, i.e. hour to hour. Results of ANOVA on repeated measures to compare transformed rates (see 'Materials and Methods') over time are summarized in Tables 2 and 3 . Worms in Moesgaard Beach sediment exhibited an increasing adjusted reworking rate over time, while those in Limfjord sediment raised their adjusted rate from Period $A$ to $B$ and showed no further significant change. Comparison of transformed rates between sediments at each time period revealed that reworking was greater 


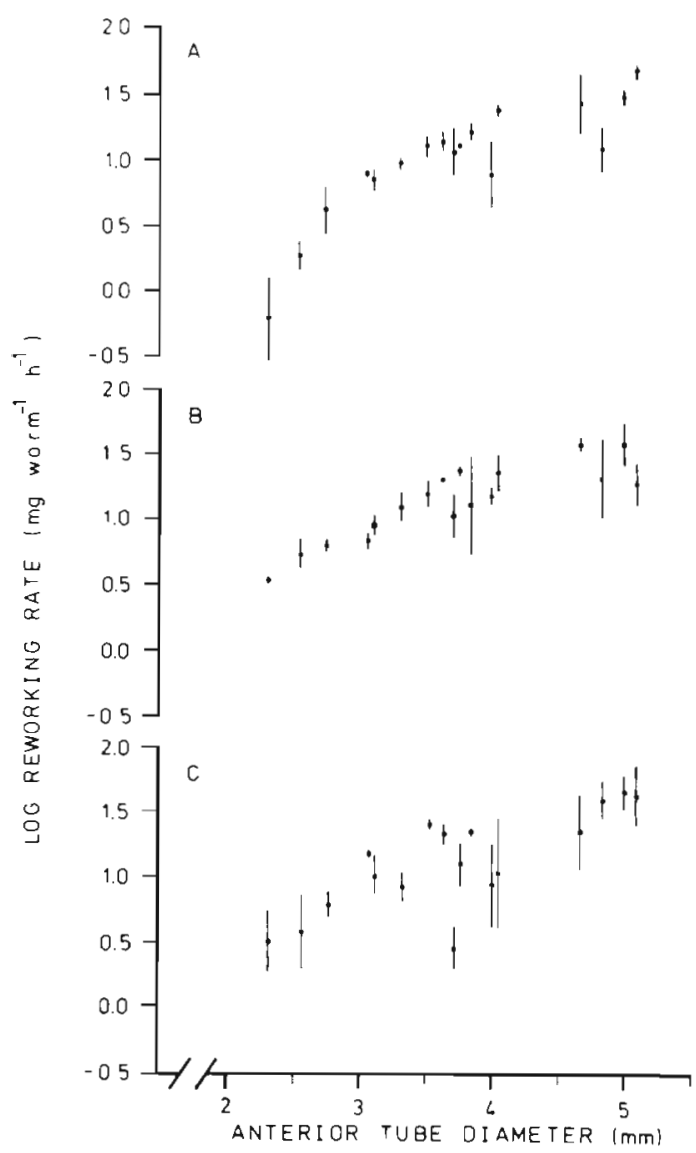

Fig. 4. Pectinaria koreni. Sediment reworking rate in Limfjord sediment over time. Values indicate the mean \pm SD of rate measurements for each individual. Period $\mathrm{A}=12$ to $36 \mathrm{~h}$, $\mathrm{Y}=0.450 \mathrm{X}-0.690, \mathrm{n}=19, \mathrm{r}^{2}=0.731$; Period $\mathrm{B}=89$ to $119 \mathrm{~h}, \mathrm{Y}=0.302 \mathrm{X}-0.018, \mathrm{n}=19, \mathrm{r}^{2}=0.760 ;$ Period $\mathrm{C}=161$ to $191 \mathrm{~h}, \mathrm{Y}=0.339 \mathrm{X}-0.131, \mathrm{n}=19, \mathrm{r}^{2}=0.576$

in Limfjord sediment during Periods A and B; in Period $C$ there was no significant difference (Table 4).

\section{Defecation and pseudodefecation rate}

Observed defecation rates and calculated pseudodefecation rates (Fig. 6 \& 7) generally followed the pattern seen in total reworking estimates, i.e. an exponential increase with increasing worm size. In the Limfjord sediment, both defecation and pseudodefecation rates increased over time and the relation between worm size and both rates became more clear. This temporal trend was not observed in Moesgaard Beach sediment.

In both sediments, the amount of material manipulated and reworked was much greater than that actually ingested. Median values of the pseudodefecation: defecation ratio ranged from 12 to 65 for worms in Limfjord sediment and from 3.9 to 10.6 for worms in

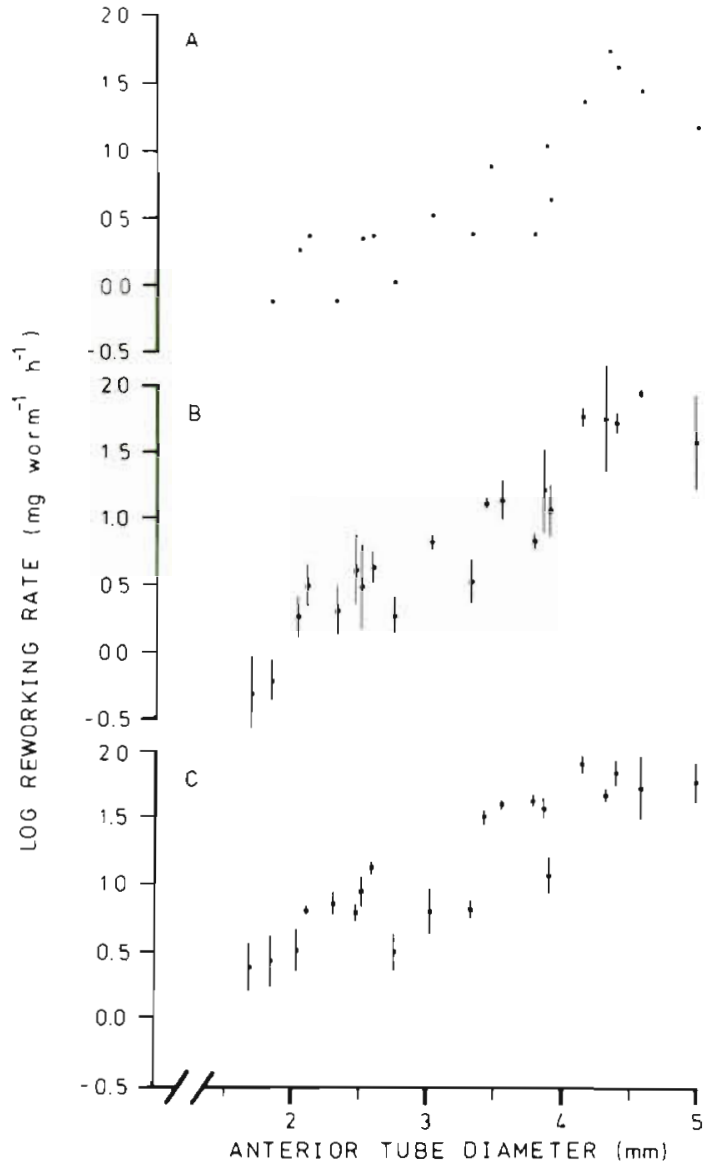

Fig. 5. Pectinaria koreni. As in Fig. 4, for worms in Moesgaard Beach sediment. Only 1 measurement was made during Period A. Period A, $Y=0.511 X-1.050, n=18, r^{2}=0.732$; Period B, $Y=0.556 X-0.933, n=21, r^{2}=0.832$; Period $C$, $\mathrm{Y}=0.470 \mathrm{X}-0.350, \mathrm{n}=21, \mathrm{r}^{2}=0.798$

Moesgaard Beach sediment (Table 5). There was no significant difference in the ratio over time in either sediment (Kruskal-Wallis test, $\mathrm{p}>0.05$ ). When between-sediment comparisons were made, the ratio was greater in Limfjord sediment during Periods A and B (Wilcoxon Rank Sum test, $\mathrm{p}<0.05$; Table 5).

\section{Particle-size selectivity}

When median particle sizes of gut contents and ambient sediments were tested for differences, significant results were obtained (Table 6 , Wilcoxon Signed Rank test, 1-tailed hypothesis, $\mathrm{p}<0.05$ ). Exclusion of values $>1000 \mu \mathrm{m}$ from the data altered the ranking of the differences between medians, but did not affect the level of significance. Therefore, among particles that it is morphologically capable of ingesting, Pectinaria koreni ingested large grains disproportionately with respect to their abundance. 
Table 2. Pectinaria koreni. ANOVA on repeated measures examining transformed reworking rates $\left(\log _{10} \mathrm{mg} \mathrm{worm}^{-1} \mathrm{~h}^{-1}, \mathrm{see}\right.$ 'Materials and Methods') over time in Limfjord sediment. Results of Newman-Keuls test indicate ranking of time periods by mean rates (low to high). Values connected by an underline are not significantly different

\begin{tabular}{|c|c|c|c|c|c|}
\hline Source of variation & & SS & $\mathrm{df}$ & MS & $\mathrm{F}$ \\
\hline Among worms & & 1.13 & 18 & & \\
\hline Within worms & & 1.34 & 38 & & \\
\hline Time period & 0.27 & 2 & & 0.13 & $4.54^{\circ}$ \\
\hline Residual & 1.07 & 36 & & 0.03 & \\
\hline Total & & 2.47 & 56 & & \\
\hline $\begin{array}{l}\cdot F_{95}(2,36)=3.27 \\
\text { Newman-Keuls Test }\end{array}$ & $A(12$ to $36 \mathrm{~h})=0.95$ & $B(89$ to $119 h)$ & $=1.09$ & $\mathrm{C}(161$ to $191 \mathrm{~h})=1.11$ & \\
\hline
\end{tabular}

Table 3. Pectinaria koreni. As in Table 2, for reworking rates over time in Moesgaard Beach sediment

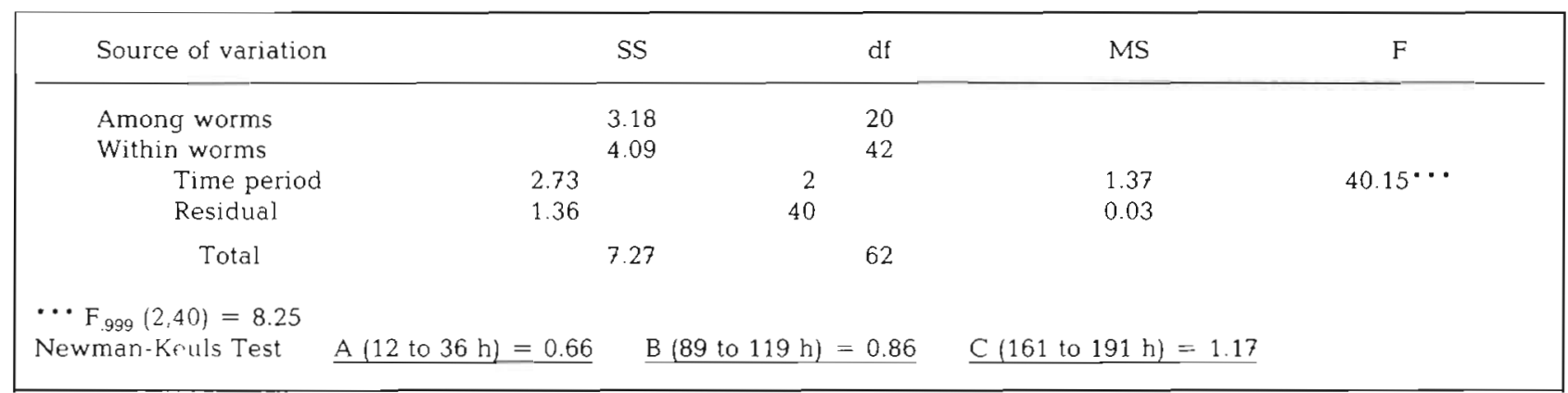

Table 4. Pectinaria koreni. Two-sample t-tests on transformed reworking rates (see 'Materials and Methods') in 2 sediments

\begin{tabular}{|c|c|c|c|c|c|}
\hline \multirow{2}{*}{\multicolumn{2}{|c|}{ Time period }} & \multicolumn{2}{|c|}{$\begin{array}{l}\log _{10} \operatorname{mg~worm}^{-1} \mathrm{~h}^{-1} \\
\text { mean }(\mathrm{SD})\end{array}$} & \multirow[t]{2}{*}{$p$ value } & \multirow[t]{2}{*}{ Result } \\
\hline & & $\begin{array}{l}\text { Lim- } \\
\text { fjord }\end{array}$ & $\begin{array}{l}\text { Moes- } \\
\text { gaard } \\
\text { Beach }\end{array}$ & & \\
\hline A & $12-36 \mathrm{~h}$ & $0.96(.22)$ & $0.66(.34)$ & 0.002 & Lim>Moes \\
\hline B & $89-119 h$ & $1.09(.14)$ & $0.86(, 25)$ & 0.001 & Lim>Moes \\
\hline C & $161-191 \mathrm{~h}$ & $1.11(.24\}$ & $1.16(.23)$ & 0.457 & ns \\
\hline
\end{tabular}

Table 5. Pectinaria koreni. Wilcoxon Rank Sum tests comparing the ratio of pseudodefecated sediment to defecated sediment in 2 sediments

\begin{tabular}{|cccccc|}
\hline Time period & \multicolumn{2}{c|}{$\begin{array}{c}\text { Median ratio } \\
\text { (number of trials) } \\
\text { Lim- } \\
\text { fjord }\end{array}$} & $\begin{array}{c}\text { Moes- } \\
\text { gaard } \\
\text { Beach }\end{array}$ & & \\
& & & & & \\
\hline & & & & & \\
A & $12-36 \mathrm{~h}$ & $65.5(12)$ & $3.9(8)$ & 0.015 & Lim $>$ Moes \\
B & $89-119 \mathrm{~h}$ & $20.0(12)$ & $10.6(14)$ & 0.045 & Lim $>$ Moes \\
C & $161-191 \mathrm{~h}$ & $12.0(14)$ & $8.9(11)$ & 0.137 & ns \\
\hline
\end{tabular}

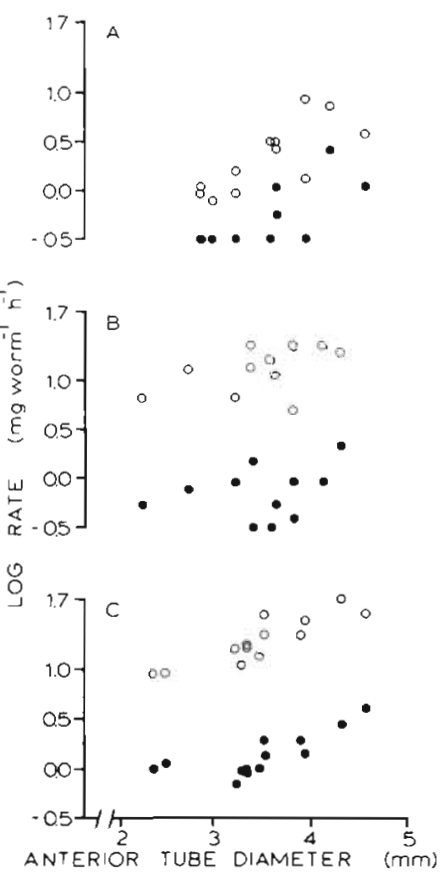

Fig. 6. Pectinaria koreni. Defecation ( $\bullet$ ) and pseudodefecation (O) rates in Limfjord sediment over time. Period $A=12$ to

$36 \mathrm{~h}$; Period B $=89$ to $119 \mathrm{~h}$; Period C $=161$ to $191 \mathrm{~h}$ 


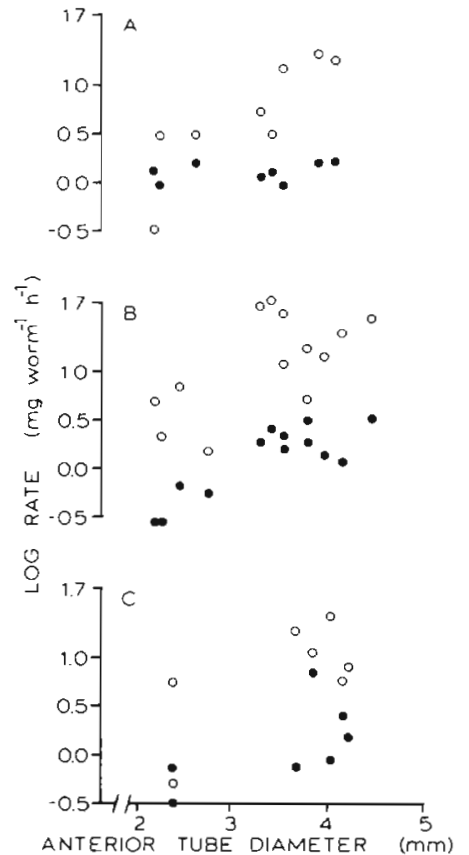

Fig. 7. Pectinaria koreni. As in Fig. 6, for worms in Moesgaard Beach sediment

Table 6. Pectinaria koreni. Median particle size $(\mu \mathrm{m})$ of sediments in guts and ambient sediments around 10 individuals. Wilcoxon Signed Rank tests are shown below. ATD = anterior tube diameter. 'Indicates values $>1000 \mu \mathrm{m}$ were eliminated

\begin{tabular}{|c|c|c|c|}
\hline $\begin{array}{l}\text { ATD } \\
(\mathrm{mm})\end{array}$ & Gut & $\begin{array}{l}\text { Ambient } \\
\text { sediment }\end{array}$ & $\begin{array}{l}\text { Ambient } \\
\text { sediment }\end{array}$ \\
\hline 4.10 & 67 & 76 & 69 \\
\hline 4.50 & 84 & 62 & 62 \\
\hline 5.50 & 131 & 62 & 62 \\
\hline 6.00 & 56 & 60 & 60 \\
\hline 6.17 & 111 & 93 & 79 \\
\hline 6.33 & 129 & 77 & 66 \\
\hline 6.42 & 100 & 69 & 62 \\
\hline 6.50 & 74 & 82 & 75 \\
\hline 7.17 & 75 & 62 & 62 \\
\hline 7.33 & 56 & 59 & 57 \\
\hline \multicolumn{2}{|l|}{ Hypotheses: } & p value & Result \\
\hline \multicolumn{2}{|c|}{$\begin{array}{c}\mathrm{H}_{0}: \text { gut }=\text { ambient } v s \\
\mathrm{H}_{1}: \text { gut }>\text { ambient }\end{array}$} & 0.042 & Gut $>$ ambient \\
\hline \multicolumn{2}{|c|}{$\begin{array}{l}\mathrm{H}_{0}: \text { gut }=\text { ambient } v S \\
\mathrm{H}_{1}: \text { gut }>\text { ambient }\end{array}$} & 0.042 & Gut $>$ ambient ${ }^{\circ}$ \\
\hline
\end{tabular}

Although there was an overall tendency to ingest large particles, individuals varied greatly in their responses (Fig. 8). To summarize these histogram data, electivity indices were averaged over all 10 worms. By particle-size category, the values were: 500 to $1000 \mu \mathrm{m}$ $(-0.13) ; 250$ to $500 \mu \mathrm{m}(-0.13) ; 125$ to $250 \mu \mathrm{m}(-0.04)$;

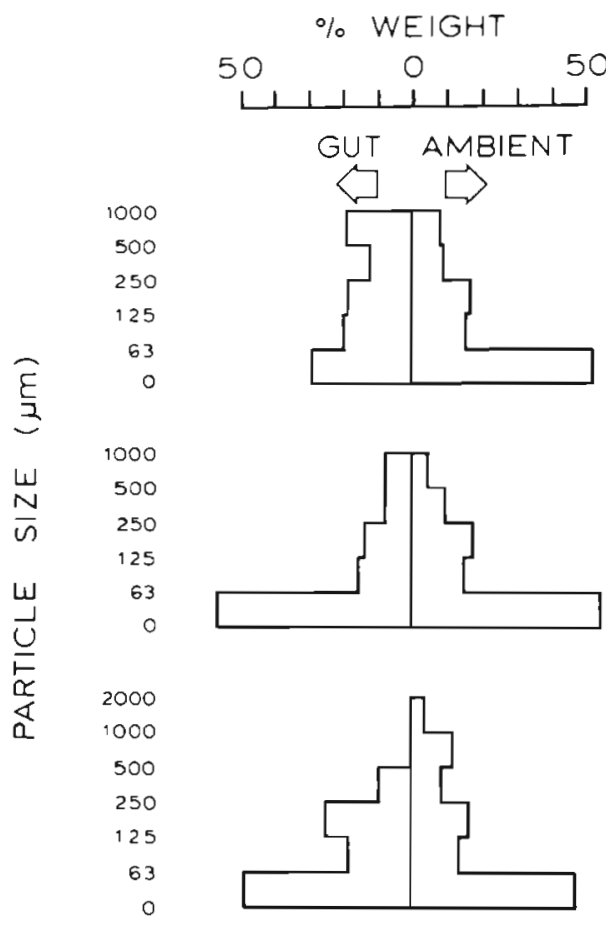

Fig. 8. Pectinaria koreni. Selected particle-size distributions of gut contents and adjacent ambient sediment. Each pair of histograms represents data for 1 specimen. The 1 st and 3 rd specimens disproportionately ingested large and small particles, respectively. The middle specimen showed essentially nonselective ingestion

63 to $125 \mu \mathrm{m}(+0.17) ;<63 \mu \mathrm{m}(-0.11)$. Therefore, the only particle sizes selected for were between 63 to $125 \mu \mathrm{m}$; all other fractions were avoided to some degree. These results showed essentially no change when decomposed into arbitrary size classes of worms. It should be stressed that these average electivity values are statistically problematic (Lechowicz 1982) and had high variances. Therefore, we conclude that while Pectinaria koreni exhibits a predilection for large particles, it also demonstrates a range of feeding responses, even among worms of the same size.

\section{DISCUSSION}

\section{Infaunal behavior}

Our observations were in substantial concordance with the descriptions of previous investigators (Watson 1928, Wilcke 1952, Schäfer 1956, 1972). We acknowledge that our observational prerequisites, thin-wall aquaria and calm water, do not duplicate natural conditions (Taghon et al. 1980, Taghon 1982), but we suggest such a laboratory setting may be less artificial in studies of subsurface, rather than surface, feeders. 
We confirmed Wilcke's (1952) report that Pectinaria koreni can forage with its tentacles at the sedimentwater interface. In so doing, the polychaete obtains a food resource presumably richer and more labile than material available at depth (Fenchel 1969, Fenchel \& Straarup 1971, Dale 1974, Johnson 1977, Novitsky 1983). This behavior, together with the observation that suspended particles can be drawn into the feeding cavern as the worm irrigates (see also Watson 1928), supports the concept that nutritional components at the sediment-water interface may be important to some organisms that usually feed at depth in the sediment (Dobbs \& Whitlatch 1982)

The 'sloppy' retrieval of particles exhibited by Pectinaria koreni has been reported before (Watson 1928) and for another pectinariid as well (Gordon 1966, Whitlatch 1974). Perhaps the polychaete's continual foraging within its feeding cavern ensures that sooner or later, it will collect any food particles previously dropped or rejected. It is puzzling, however, that the worm rejects some particles visually indistinguishable from others it ingests, e.g. fecal pellets. Factors known to influence particle selection in tentacular-feeding polychaetes include particle size, presence of organic coating, surface texture, and specific gravity (Whitlatch 1974, Self \& Jumars 1978, Taghon 1982). In the case of $P$. koreni, it may be that chemical cues are important as well. In viewing scanning electron micrographs of the worm's tentacles, we were impressed by their porosity (Fig. 9). It is tempting to suggest that the vast surface area provided by this morphology harbors chemosensory receptors, but we have no evidence. An ultrastructural study of these tissues would likely be a rewarding research effort.

Fauchald \& Jumars (1979) postulated that pectinariid polychaetes form U-shaped burrows in hypoxic, highnutrient, fine-grained sediment. Individuals living in coarse sediment poor in food should exhibit higher motility and no permanent burrow system. Our observations of Pectinaria koreni in sediments from the Limfjord (fine) and Moesgaard Beach (coarse) were in agreement with their postulates. Only in Limfjord sediment did worms establish U- (or V-shaped) burrows.

\section{Sediment processing}

Reworking rate of Pectinaria koreni increased exponentially with increasing anterior tube diameter. This pattern again emerged when equivalent reworking rates were calculated for other pectinariids (Table 7 ). Since total reworking and defecation are positively

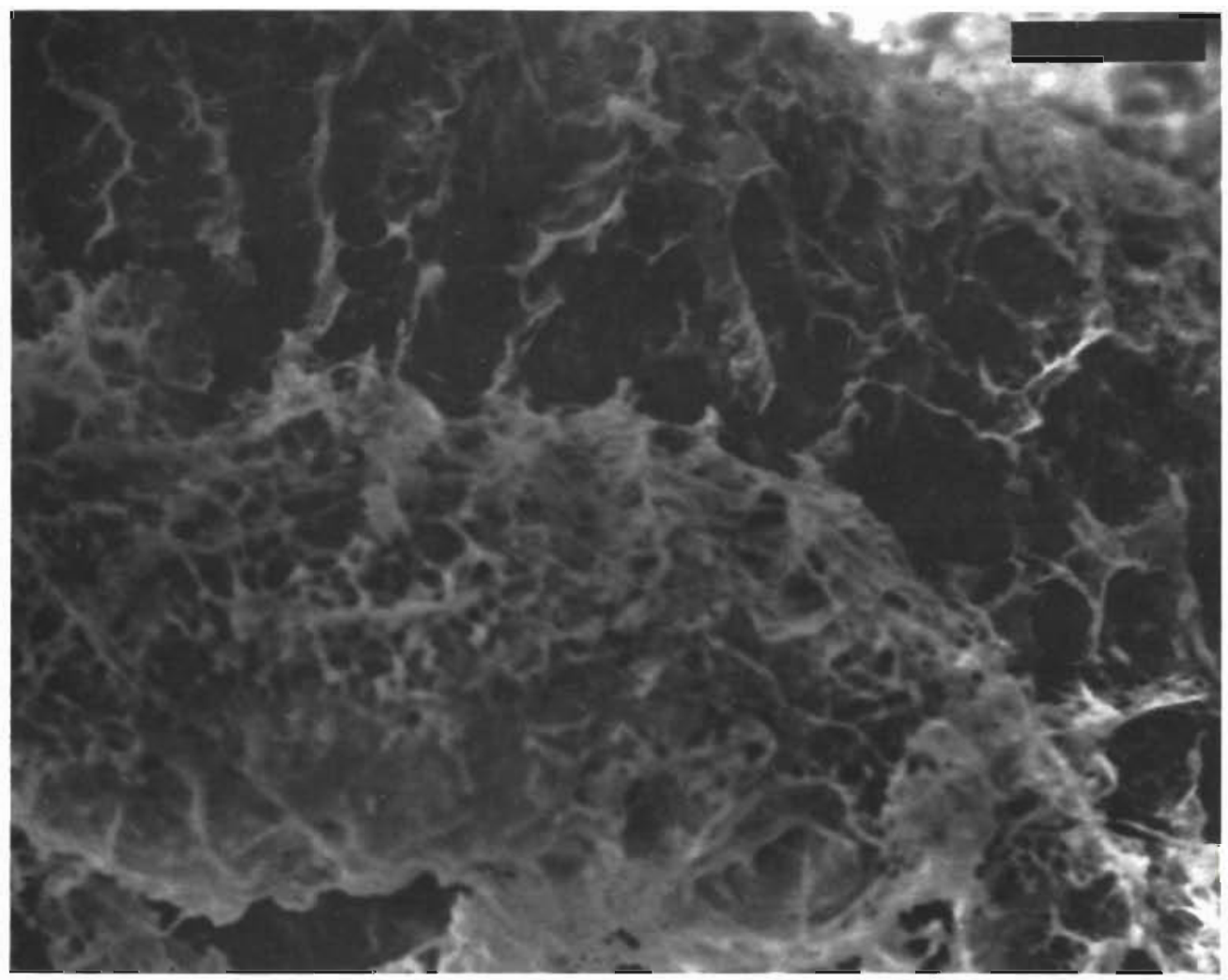

Fig. 9. Pectinaria koreni. Scanning electron micrograph of a tentacle, oblique view. Note especially the highly porous nature of the median groove. Black bar represents $40 \mu \mathrm{m}$ 
Table 7. Laboratory studies of sediment reworking by Pectinaria spp

\begin{tabular}{|c|c|c|c|c|c|}
\hline Source & Species & Population from & $\begin{array}{l}\text { Anterior tube } \\
\text { diameter (mm) }\end{array}$ & Temperature $\left({ }^{\circ} \mathrm{C}\right)$ & $\begin{array}{l}\text { Rate } \\
\left(\mathrm{mg} \text { worm }{ }^{-1} \mathrm{~h}^{-1}\right)\end{array}$ \\
\hline Gordon (1966) & P. gouldii & $\begin{array}{l}\text { Barnstable Harbor, } \\
\text { Massachusetts, USA }\end{array}$ & 4.5 to $6.6^{\mathrm{a}}$ & 18 to 22 & 177 to $287^{b}$ \\
\hline $\begin{array}{l}\text { Whitlatch \& } \\
\text { Weinberg (1982) }\end{array}$ & P. gouldii & $\begin{array}{l}\text { Fishers Island, } \\
\text { New York, USA }\end{array}$ & $\begin{array}{l}3.5 \text { to } 3.9 \\
4.0 \text { to } 4.3\end{array}$ & $\begin{array}{l}15.5 \\
15.5\end{array}$ & $\begin{array}{l}3 \text { to } 22^{c} \\
28 \text { to } 88\end{array}$ \\
\hline Nichols (1974) & P. californiensis & $\begin{array}{l}\text { Alki Point, } \\
\text { Puget Sound, } \\
\text { Washington, USA }\end{array}$ & 3.5 to $6.9^{d}$ & 10 & 3 to $12^{\mathrm{e}}$ \\
\hline Present study & P. koreni & $\begin{array}{l}\text { Aarhus Bay and } \\
\text { Rønbjerg, Denmark }\end{array}$ & $\begin{array}{l}1.68 \text { to } 5.00^{f} \\
2.32 \text { to } 5.08^{g}\end{array}$ & $\begin{array}{l}15 \\
15\end{array}$ & $\begin{array}{l}<1 \text { to } 83 \\
<1 \text { to } 47\end{array}$ \\
\hline \multicolumn{6}{|c|}{$\begin{array}{l}\text { Gordon tested worms } 4 \text { to } 6 \mathrm{~cm} \text { in length; we calculated anterior tube diameter from a formula determined by Busch \& } \\
\text { Loveland (1975), ATD (in mm) }=0.108 \mathrm{~L} \text { (in mm) }+0.146 \\
\text { b Based on range of means presented in Gordon's Fig. 2, divided by } 24 \mathrm{~h} \\
\text { c Considered to be 'feeding rate' } \\
\text { d Nichols tested worms with a cephalic plate width (CPW) from approximately } 3 \text { to } 6 \mathrm{~mm} \text {. Anterior tube diameter (ATD) was } \\
\text { calculated from a formula determined in the present study of } P \text {. koreni, ATD (in mm) }=1.08 \mathrm{CPW} \text { (in mm) } 0.282 \\
\text { e Calculated from Nichol's equation, log reworking rate }=2.05 \text { logCPW (in mm) }-0.529 \text {, for worms with CPW from } 3 \text { to } 6 \mathrm{~mm} \\
\text { f Worms tested in sediment from Moesgaard Beach } \\
\text { g Worms tested in sediment from the Limfjord }\end{array}$} \\
\hline
\end{tabular}

correlated in pectinariids (Nichols 1974; this study, Fig. 4 to 7 ), and $\log _{10}$ dry weight of Pectinaria is linearly related to its anterior tube diameter (Busch \& Loveland 1975), these results conform to perceptions concerning ingestion rates of deposit feeders. That is, ingestion rate is highly correlated with individual dry weight over an array of taxonomic groups (Hargrave 1972, Cammen 1980).

A major concern of this research was to compare sediment processing by Pectinaria koreni in 2 distinct types of sediment. It should be emphasized that these sediments differed not only in grain size, but also in particle composition, percent combustibles, and other covariates, e.g. particle specific gravity and surface texture (Shelf \& Jumars 1978). The problem of covariation is inherent in comparative work with sediments from the field and unfortunately is not always predictable (see Cammen 1982). Transformed reworking rates were greater in Limfjord sediment (fine) than in Moesgaard Beach sediment (coarse) during Periods A and $B$ and were not significantly different in Period C (Table 4). These results appear incongruent with those of Whitlatch \& Weinberg (1982), who showed that another pectinariid increased its reworking rate ('feeding rate' in their paper) with increasing particle size. However, they used size-fractionated experimental sediments generally much smaller than Moesgaard Beach sediment and much cleaner than Limfjord sediment. Furthermore, they first baked the sediments and recolonized them with bacteria. Therefore, in light of differences in design between their experiments and ours, we feel it unwarranted to consider the results contradictory.

Few researchers have specifically addressed the change in laboratory reworking rates over time (Hylleberg 1975, Powell 1977). In the present study, transformed reworking rates in Limfjord sediment increased between the first 2 measurement periods, then leveled off in the third (Table 2). This pattern would be expected if acclimation were necessary to achieve a constant level of activity. In Moesgaard Beach sediment, however, there was an increase in rate between each consecutive measurement period (Table 3). Acclimation may occur more slowly in coarse sediment. Alternatively, the worms may have responded to this sediment's very low food value (based on percent combustibles) by increasing their reworking rate (Gordon 1966, Cammen 1980; but see counter-examples in Taghon 1981).

Ratios of pseudodefecation rate to defecation rate determined in this study (Table 5) were greater than those reported for other pectinariids, viz., Pectinaria gouldii, 2:1 (Gordon 1966); $P$. californiensis, 3:1 (Nichols 1974). In sediment from the Limfjord, the median ratio ranged as high as 65:1. Apparently, food particles were greatly outnumbered by non-food particles in this debris-laden sediment.

Further insight into the relative availability of food particles may be obtained by examining temporal patterns of defecation and pseudodefecation. If food particles were found in constant proportion to particles that are pseudodefecated, then both defecation and 
pseudodefecation rates should parallel total reworking rate. In our experiments, such was clearly the case in Limfjord sediment (Fig. 6), especially after a period of acclimation. That the pattern was indistinct in the coarser Moesgaard Beach sediment (Fig. 7) suggests that food particles were encountered in less-than-constant proportions.

\section{Particle-size selectivity}

The feeding behavior of pectinariids confounds a current perception of optimal foraging by deposit feeders, i.e. that animals should select smaller particles because their food value is higher (Taghon et al. 1978, Taghon 1982). However, the apparently abberrant particle-size selectivity of pectinariids may effectively concentrate particles of high food value. Wilcke (1952) reported foraminifers, ciliates, and (harpacticoid?) copepods in the gut of Pectinaria koreni, although he thought detrital supplementation of this predatory diet was very probable. Digestion and assimilation of meiofauna, however, are not necessarily the consequences of their ingestion. Ronan (1977) found that most nematodes, crustaceans, and foraminifers passed unharmed through the gut of deposit-feeding polychaetes, including a pectinariid, although about $30 \%$ of the smallest copepods and polychaetes were killed and partially digested. The intestine of $P$. koreni secretes an amylase, a trypsin, and probably a lipase (Brasil 1904), but we have no idea of its efficacy in digesting meiofauna. We looked for large meiofauna in guts of worms collected in the field but saw them only infrequently and without signs of digestion.

If Pectinaria koreni's selection for large particles is not related to predation, why else might it behave so? Whitlatch (1974) found that in the food resource available to another pectinariid, the percent of mineral grains encrusted by organics increased with increasing particle size. Therefore, the worm's predilection for large particles increased its organic intake compared to random foraging or ingestion of smaller particles.

Perhaps most importantly, Pectinaria koreni's particle-selection behavior increases its chances of ingesting fecal material. Fecal pellets of a co-occurring, deposit-feeding semelid bivalve mollusc, Abra alba, were abundant in guts of worms from the Limfjord and Aarhus Bay. Pectinariids and semelid or tellinid clams often are found in association (Peres 1982) and a trophic interaction seems quite possible. Coprophagy has been reported in other pectinariids (Whitlatch 1974, Ronan 1977) and is believed to play an important nutritive role within the deposit-feeding guild (e.g. Newell 1965, Frankenberg \& Smith 1967, Hansen 1978, Guidi \& Tito de Morais 1983). In the case of
P. koreni, Abra fecal pellets pass through the gut intact (pers. obs. by F. C. D.) so any food benefit obtained must be through digestion of organics and microbes on the pellet surface and/or absorption of soluble constituents contained within the pellet.

If nothing else, the foregoing discussion may persuade the reader that in natural or quasi-natural sediments, tests of foraging theories cannot be rigorously made using deposit feeders and particle-size data. A mineral grain, a fecal pellet, and an ostracod may be of exactly the same size, but potentially of vastly different food value.

Finally, it should be noted that the present study has not distinguished between active and passive selection of particles. Although we consider that aspects of active selection certainly exist (e.g. foraging at the sediment-water interface), an altemative school of thought explains selection strictly on a mechanical basis related to the morphology of feeding tentacles (Whitlatch 1980, Jumars et al. 1982).

Acknowledgements. We are grateful to Prof. T. Fenchel and all others at the Institute for Genetics and Ecology, Aarhus University, for their support and assistance. In particular, we thank T. H. Blackbum, J. Hylleberg, K. T. Jensen, B. B. Jørgensen, N. O. G. Jørgensen, S. Kolding, E. Kristensen, M. V. Nielsen, and N. P. Revsbech. We appreciate reviews of earlier versions of this paper by K. R. Carman, J. R. Weinberg, and anonymous reviewers. J. R. Weinberg also suggested the transformation used to analyse the reworking data. M. V. Nielsen identified the Abra fecal pellets. G. Liebezeit kindly provided 2 references otherwise unobtainable.

\section{LITERATURE CITED}

Bachler, B. (1981). Untersuchungen zur Auswirkung von Pectinaria koreni Malmgren (1865) auf den Wasseraustausch über die Sediment-Wasser-Grenzfläche. Dissertation, Hamburg Univ.

Brasil, L. (1904). Contribution a la connaissance de l'appareil digestif des annélides polychètes. L'épithélium intestinal de la Pectinaire. Archs Zool. Exp. gén. (Series 4) 2: 91-255

Busch, D. A., Loveland, R. E. (1975). Tube-worm-sediment relationships in populations of Pectinaria gouldii (Polychaeta: Pectinariidae) from Barnegat Bay, New Jersey, USA. Mar. Biol. 33: 255-264

Cammen, L. M. (1980). Ingestion rate: An empirical model for aquatic deposit feeders and detritivores. Oecologia (Berl.) 44: $303-310$

Cammen, L. M. (1982). Effect of particle size on organic content and microbial abundance within four marine sediments. Mar. Ecol. Prog. Ser. 9: 273-280

Dale, N. G. (1974). Bacteria in intertidal sediments: Factors related to their distribution. Limnol. Oceanogr. 19: $509-518$

Dobbs, F. C., Whitlatch, R. B. (1982). Aspects of deposit feeding by the polychaete Clymenella torquata. Ophelia 21: $159-166$

Fauchald, K., Jumars, P. A. (1979). The diet of worms: A study of polychaete feeding guilds. Oceanogr. mar. Biol. A. Rev. 17: $193-284$ 
Fenchel, T (1969). The ecology of marine microbenthos. IV: Structure and function of the benthic ecosystem, its chemical and physical factors, and the microfauna communities with special reference to the ciliated Protozoa. Ophelia 6: $1-182$

Fenchel, T., Straarup, B. J. (1971). Vertical distribution of photosynthetic pigment and the penetration of light in marine sediments. Oikos 22: 172-182

Frankenberg, D., Smith, K. L. (1967). Coprophagy in marine animals. Limnol. Oceanogr. 12:443-450

Gordon, D. C., Jr. (1966). The effects of the deposit feeding polychaete Pectinaria gouldii on the intertidal sediments of Barnstable Harbor. Limnol. Oceanogr. 11: 327-332

Guidi, L. D., Tito de Morais, A. (1983). Ascidian faecal pellets and their utilization by an epibenthic amphipod. J. exp. mar. Biol. Ecol. 71: 289-298

Hansen, M. D. (1978). Nahrung und Freßverhalten bei Sedimentfressern dargestellt am Beispiel von Sipunculiden und Holothurien. Helgoländer Meeresunters. 31: 191-221

Hargrave, B. T. (1972). Prediction of egestion by the depositfeeding amphipod Hyalella azteca. Oikos 23: 116-124

Hollander, M., Wolfe, D. A. (1973). Nonparametric statistical methods. Wiley, New York

Hylleberg, J. (1975). Selective feeding by Abarenicola pacifica with notes on Abarenicola vagabunda and a concept of gardening in lugworms. Ophelia 14: 113-137

Ivlev, V.S. (1961). Experimental ecology of the feeding of fishes. Yale University Press, New Haven

Johnson, R. G. (1977). Vertical variation in particulate matter in the upper twenty centimeters of marine sediments. J. mar. Res, 35: 273-282

Jumars, P. A., Self, R. F. L., Nowell, A. R. M. (1982). Mechanics of particle selection by tentaculate deposit feeders. J. exp. mar. Biol. Ecol. 64: 47-70

Lechowicz, M. J. (1982). The sampling characteristics of electivity indices. Oecologia (Berl.) 52:22-30

Lindroth, A. (1941). Atmungsventilation der Polychäten. Z. vergl. Physiol. 28: 485-532

Newell, R. (1965). The role of detritus in the nutrition of two marine deposit feeders, the prosobranch Hydrobia ulvae and the bivalve Macoma balthica. Proc. Zool. Soc. 144: $25-45$

Nichols, F. H. (1974). Sediment turnover by a deposit-feeding polychaete. Limnol. Oceanogr. 19: 945-950

Nichols, F. H. (1977). Dynamics and production of Pectinaria koreni (Malmgren) in Kiel Bay, West Germany. In: Keegan, B. F., Ceidigh, P. O., Boaden, P. J. S. (ed.) Biology of benthic organisms. Pergamon, Oxford, p. 453-463

Nicolaidou, A. (1983). Life history and productivity of Pectinaria koreni Malmgren (Polychaeta). Estuar. coast. Shelf Sci. 17: 31-43

Novitsky, J. A. (1983). Heterotrophic activity throughout a vertical profile of seawater and sediment in Halifax Harbor, Canada. Appl. environ. Microbiol. 45: 1753-1760

Peres, J. M. (1982). Major benthic assemblages. In: Kinne, $O$. (ed.) Marine ecology, Vol. V, Ocean management, Part 1 , Zonations and organismic assemblages. Wiley, New York, p. $373-522$
Powell, E. N. (1977). Particle size selection and sediment reworking in a funnel feeder, Leptosynapta tenuis (Holothuroidea, Synaptidae). Int. Revue ges. Hydrobiol. 62: $385 \sim 408$

Reise, K. (1981). High abundance of small zoobenthos around biogenic structures in tidal sediments of the Wadden Sea Helgoländer Meeresunters. 34: 413-425

Rhoads, D. C. (1963). Rates of sediment reworking by Yoldia limatula in Buzzards Bay, Massachusetts, and Long Island Sound. J. sedim. Petrol. 33: 723-727

Rhoads, D. C. (1974). Organism-sediment relations on the muddy sea floor. Oceanogr. mar. Biol. A. Rev. 12: 263-300

Ronan, T. E., Jr. (1977). Formation and paleontologic recognition of structures caused by marine annelids. Paleobiology 3: $389-403$

Schäfer, W (1956). Wirkungen der Benthos-Organismen auf den jungen Schichtverband. Senckenberg. leth. 37 183-263

Schäfer, W. (1972). Ecology and palaeoecology of marine environments. Craig, G. Y. (ed.) and Oertel, I. (Translator), University of Chicago Press, Chicago

Self, R. F. L., Jumars, P. A. (1978). New resource axes for deposit feeders? J. mar. Res. 36: 627-641

Taghon, G. L. (1981). Beyond selection: Optimal ingestion rate as a function of food value. Am. Nat. 118: 202-214

Taghon, G. L. (1982). Optimal foraging by deposit-feeding invertebrates: Roles of particle size and organic coating. Oecologia (Berl.) 52: 295-304

Taghon, G. L., Nowell, A. R. M., Jumars, P. A. (1980). Induction of suspension feeding in spionid polychaetes by high particulate fluxes. Science, N. Y. 210: 562-564

Taghon, G. L., Self, R. F. L., Jumars, P. A. (1978). Predicting particle selection by deposit feeders: $A$ model and its implications. Limnol. Oceanogr. 23: 752-759

Vouvelle, J. (1971). Sélection des grains du tube chez les Amphictenidae (Polychètes Sédentaires). Cah. Biol. mar. 12: $365-380$

Vouvelle, J. (1973). Evolution de la taille des grains du tube arénacé en fonction de la croissance chez Pectinaria (Lagis) koreni Malmgren (Polychète Sédentaire). Ophelia 10: $169-184$

Watson, A. T. (1928). Observations of the habits and life history of Pectinaria (Lagis) koreni. Proc. Trans. Liverpool Biol. Soc. 42: 25-60

Whitlatch, R. B. (1974). Food-resource partitioning in the deposit-feeding polychaete Pectinaria gouldii. Biol. Bull. mar biol. Lab., Woods Hole 147: 227-235

Whitlatch, R. B. (1980). Foraging in the deposit-feeding polychaete Pectinaria gouldii: testing the energy-optimization hypothesis. Am. Zool. 20: 920

Whitlatch, R. B., Weinberg, J. R. (1982). Factors influencing particle selection and feeding rate in the polychaete $\mathrm{Cis}$ tenides (Pectinania) gouldii. Mar. Biol. 71: 33-40

Wilcke, D. E. (1952). Beobachtungen über den Bau und die Funktion des Röhren- und Kammersystems der Pectinaria koreni Malmgren. Helgoländer wiss. Meeresunters. 4: $130-137$

Winer, B. J. (1971). Statistical principles in experimental design, 2nd ed. McGraw-Hill, New York 